\title{
Gis Application To Zone Surface Water Quality According To WQI - The Case Of Tri An Reservoice, Vietnam
}

\author{
Le Trong Dieu Hien, Pham Van Tat, Huynh Anh Tuan
}

\begin{abstract}
GIS is a powerful tool for researches relating to many environmental problems and especially in water quality management such as sustainable water- use plan, assessing water quality and managing water resources on a local or regional scale. The models are linked with GIS for output data and results presentation. In this paper the interpolation function in GIS technology and Surfer software were applied to zone the surface water quality in Tri An Reservoir according to parameters: $\mathrm{pH}$, $\mathrm{DO}, \mathrm{BOD}_{5}, \mathrm{COD}, \mathrm{TSS}, \mathrm{NH}_{4}^{+}, \mathrm{P}_{-} \mathrm{PO}_{4}$, turbidity and coli form. $\mathrm{A}$ series of data related to these parameters in three years 2010 , 2013 and 2014 was collected to be input data for the interpolation. Then, the interpolation maps of parameters through years were built to compare and assess surface water quality in Tri An Reservoir.
\end{abstract}

Keywords: GIS, interpolation, water quality

\section{Introduction}

Tri An reservoir lies between latitudes $10^{\circ} 00^{\prime}$ to $12^{0} 20^{\prime}$ North and longitudes $107^{\circ} 00^{\prime}$ to $108^{\circ} 30^{\prime}$ East. Tri An is the largest reservoirs in Vietnam with $324 \mathrm{~km}^{2}$ areas, an average depth of $8.5 \mathrm{~m}$, about $44 \mathrm{~km}$ in length and has a maximum width of $10 \mathrm{~km}[1,2]$. Reservoir was put in operation in 1987 and has an important role in storing and supplying water, making the hydraulic power equable, controlling flood and salty in downstream, aqua- culturing, travelling, and protecting the ecosystem. With a catchment area of approximately $14,800 \mathrm{~km}^{2}$, an average annual outflow of 15,100 million $\mathrm{m}^{3}$ and total volume of 2,765 million $\mathrm{m}^{2}$ (Fig. 1), Tri An also supplies livelihoods of millions of local people in Binh Duong, Dong Nai provinces and Hochiminh city.

\section{Le Trong Dieu Hien, Huynh Anh Tuan}

University of Thu Dau Mot

Vietnam

Pham Van Tat

University of Hoa Sen

Vietnam

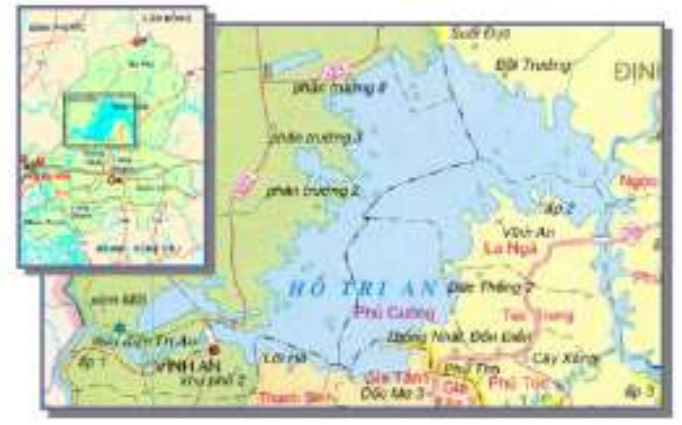

Figure 1. Geographic Map of Tri An Reservoir

Although Tri An reservoir has the great roles, however recently, the water quality of reservoir has a downward tendency, fisheries resources have tended to be overexploited [3, 4]. The main reasons which explain for this situation include ineffective or inappropriate management measures; waste water into the lake from factories, pig farms near the lake and fisheries catch. According to results which were monitored in 2013, the water quality of reservoir is in danger especially at the parts which pass through Vinh An, Phu Cuong and La Nga town [5].

To access the water quality of rivers, reservoirs, canals, and lakes, many studies which base on the monitored special parameters to compare to the Nation standards or International standards have been carried out in Vietnam and other countries in the world as well. However, this research method has limitation that does not show the general tendency so it is difficult to inform situation of water quality in a special place to citizen. To overcome this drawback, it is essential to have a new method which integrated separated parameters into a general parameter. Therefore, WQI Water Quality Index makes the water quality comparison through years or different locations easily. In this study, authors would apply GIS to interpolate the WQI to build up the water quality maps. This would contribute to improve the water quality management in Tri An Reservoir.

The method using interpolation function in GIS has been applying in many studies such as studies of Yammani (2007) [6], Rangan et al. (2008) [7], Babiker et al. (2007) [8], Raikar \& Sneha (2012) [9], Noha Donia(2011) [10], Kumar et al. (2011) [11] etc. 


\section{A) Input data}

II. Methodology

A monitoring program was established by Centre of technology and information- Dong Nai department of natural resources and environment. Water samples were collected 4 times a year from 11 stations covering different areas around the lake shown as Fig. 2. Nine physicochemical parameters namely $\mathrm{pH}, \mathrm{DO}, \mathrm{COD}, \mathrm{BOD}_{5}, \mathrm{~N}_{-} \mathrm{NH}_{4}$, $\mathrm{P}_{-} \mathrm{PO}_{4}$, Coliform, TSS, and Turbidity were used to calculate the water quality index (WQI). Besides, the data including space data, property data of the lake were also the input data in this study.

\section{B) WQI Calculation}

The conventional approach of expressing different parameters of water quality in varying units is well accepted by water resource experts. However, it is not readily understood by the general public and policymakers who have profound impact on water resource policies. Thus, the need for expressing water quality in a format that is simple and easily understood by common people has been recognized for a long time. Experts have worked internationally - including in the United States - for the

past several years and have designed the term Water Quality Index (WQI). The WQI takes the complex scientific information and synthesizes into a single number between zero and 100 (Table 1), by normalizing the observed values to subjective rating curves. It summarizes the relative changes in the underlying group of the water-quality variable. WQI is easily comprehended and appreciated by common citizens and policy makers. It can also help in meeting regulations and making personal lifestyle adaptations for the benefit of the environment. Several

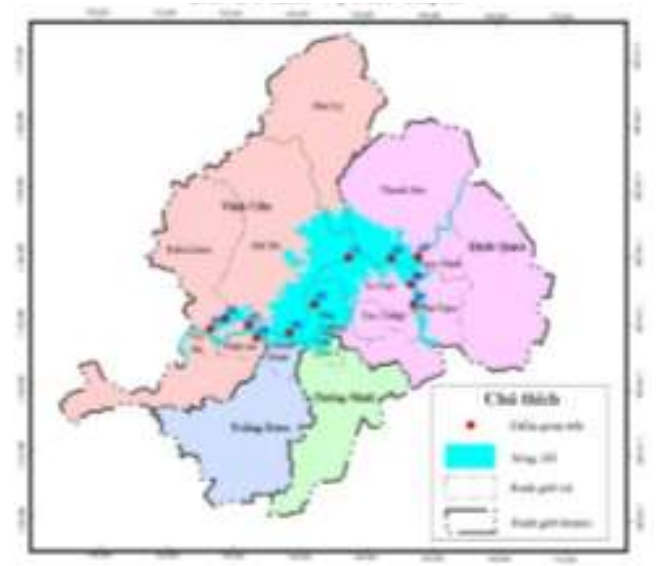

Figure 2. Map of sample locations

organizations in the United States and around the world including United Nations have adopted the WQI concept for expressing the water quality for their water resources [12].

In this research, the water quality index is calculated using the equation developed by Ministry of natural resources and environmental of Vietnam according to 879 /QĐ-TCMT [12]. The formula 1 is used to calculate the WQI:

$$
W Q I=\frac{W Q I_{p H}}{100}\left[\frac{1}{5} \sum_{a=1}^{5} W Q I_{a} * \frac{1}{2} \sum_{b=1}^{2} W Q I_{b} * W Q I_{c}\right]^{1 / 3}
$$

Where $\mathrm{WQI}_{a}$ values include the corresponding value WQI to three variables $\mathrm{DO}, \mathrm{BOD}_{5}, \mathrm{COD}$, and $\mathrm{NH}_{4}, \mathrm{P}_{-} \mathrm{PO}_{4}$; $\mathrm{WQI}_{b}$ values involve the value $\mathrm{WQI}_{T S S}, \mathrm{WQI}_{\text {turbility }}$ and the value $\mathrm{WQI}_{\text {Coli }}$ with the symbol $\mathrm{WQI}_{c}$.

TABLE 1: WQI SCALE FROM MINISTRY OF NATURAL RESOURCES AND ENVIRONMENTAL OF VIETNAM, 2011 [1]

\begin{tabular}{lll}
\hline WQI value & Quality level & Color \\
\hline $91-100$ & Excellent water quality & Blue \\
$76-90$ & Good water quality & Green \\
$51-75$ & Medium or average water quality & Yellow \\
$26-50$ & Fair water quality & Orange \\
$0-25$ & Poor water quality & Red \\
\hline
\end{tabular}

\section{C) Concept of IDW interpolation method}

The base map was georeferenced and digitized by using MapInfo software for spatial analysis. Spatial interpolation technique through Inverse Distance Weighted (IDW) approach has been used in the study to delineate the distribution of water pollutants. The Inverse Distance Weighted (IDW) referred to as deterministic interpolation methods because they assign values to locations based on the surrounding measured values and on specified mathematical formulas that determine the smoothness of the resulting surface. This method uses a defined or selected set of sample points for estimating the output grid cell value. The below formula presents for IDW interpolation 
Proc. of The Third Intl. Conf. On Advances in Applied Science and Environmental Technology - ASET 2015 Copyright (C) Institute of Research Engineers and Doctors, USA .All rights reserved.

ISBN: 978-1-63248-084-2 doi: 10.15224/ 978-1-63248-084-2-32

Where $D_{\mathrm{ij}}$ is the separate distance from point $i$ to $j ; p$ is power value. In this paper we used $\mathrm{p}=2$.

$$
Z\left(S_{0}\right)=\sum_{i=1}^{n} \lambda_{i} Z\left(S_{i}\right) \text { with } \lambda_{j}=\frac{D_{i j}^{-p}}{\sum_{i=1}^{n} D_{i j}^{-p}}(2)
$$

\section{Result and discussion A) WQI of indicators}

TABLE 2: WQI RESULTS OF INDICATORS IN 2014

\begin{tabular}{cllllllllll}
\hline Location & $\mathbf{p H}$ & DO & COD & BOD $_{\mathbf{5}}$ & TSS & $\mathbf{N}^{-N H_{4}}$ & Coli-form & Turbility & P-PO $_{4}$ & WQI total \\
\hline 1 & 100 & 100 & 96 & 95 & 100 & 74 & 100 & 96 & 100 & 97 \\
2 & 100 & 100 & 96 & 100 & 100 & 79.1 & 100 & 97 & 100 & 98 \\
3 & 100 & 100 & 100 & 100 & 100 & 84.9 & 100 & 96.7 & 100 & 98 \\
4 & 100 & 100 & 89 & 92.5 & 100 & 80.4 & 100 & 97.3 & 100 & 97 \\
5 & 100 & 99.1 & 88 & 90 & 100 & 84 & 100 & 92.3 & 100 & 96 \\
6 & 100 & 100 & 82 & 87.5 & 94 & 74.7 & 100 & 66.5 & 100 & 89 \\
7 & 100 & 100 & 99 & 92.5 & 63.3 & 73.7 & 100 & 45.1 & 100 & 80 \\
8 & 100 & 93.8 & 72.3 & 95 & 100 & 73.7 & 89 & 58 & 100 & 85 \\
9 & 100 & 100 & 78 & 90 & 87 & 77.6 & 100 & 49.3 & 100 & 85 \\
10 & 100 & 99 & 94 & 92.5 & 100 & 81 & 100 & 100 & 100 & 98 \\
11 & 100 & 100 & 89 & 85 & 100 & 73.3 & 100 & 81 & 100 & 93 \\
\hline
\end{tabular}

\section{B) Interpolation results}

\section{1) $W Q I_{p H}$}

According to the results of calculation, $\mathrm{WQI}_{\mathrm{pH}}$ of all positions in Tri An reservoir are 100 in 2010, 2013 and 2014. It means that the parameter of $\mathrm{pH}$ in Tri An reservoir has been still good. Therefore, management board of reservoir needs to implement some control methods to remain this situation of reservoir.

\section{2) $W Q I_{D O}$}

$\mathrm{WQI}_{\mathrm{DO}}$ of Tri An water area fluctuated from 80 to 100 in 2010 which was in quite good situation (Fig. 3a). In other words, the quality of water area in this year was suitable for running water. However, there was a decrease in water quality in 2013 especially the quality in the middle of reservoir (Fig. 3b). In 2014, the water quality of reservoir improved. The parameter of $\mathrm{WQI}_{D O}$ fluctuated from 94 to 100 (Fig. 3c).

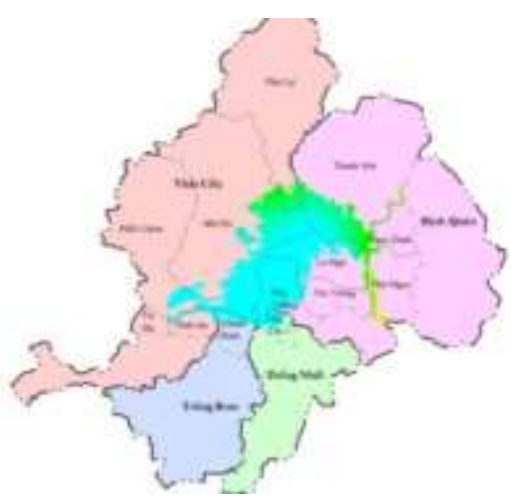

a) 2010

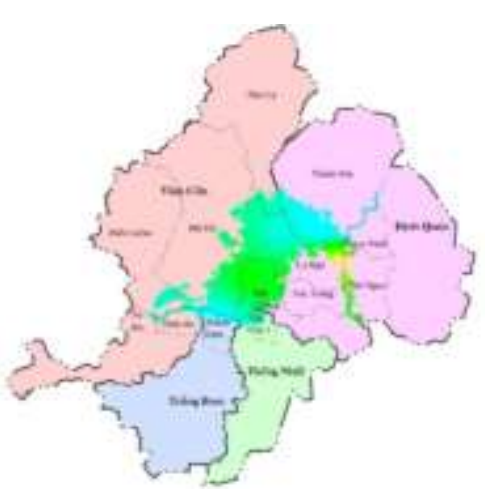

b) 2013

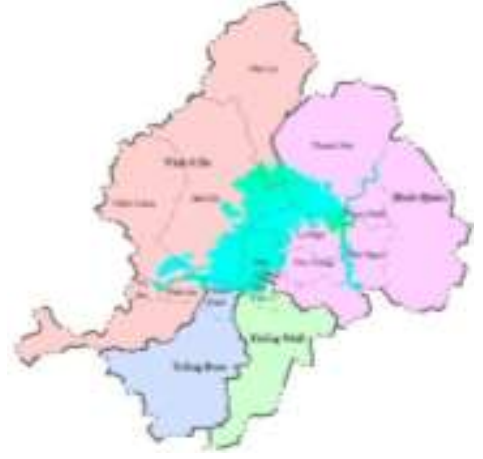

c) 2014

$$
\text { Note: } \quad(91,100) ; \quad \square(76,90) ; \quad(50,75) ; \quad \square \quad(25,50) ; \quad \square(1,25) \text {; }
$$

Figure 3: Tendency of $W Q I_{D O}$ 


\section{3) WQI}

The water quality according to $\mathrm{WQI}_{C O D}$ in 2010 fluctuated from 75 to 100 , especially the quality water in the middle of reservoir was the best (Fig. 4a). However, in 2103 , there was a light polluted signal because there was a considerable amount of wastewater with high content of organic substances which discharged into revervoir (figure
$4 \mathrm{~b}$ ), the parameter of $\mathrm{WQI}_{C O D}$ ranged from 70 to 74 , only the 'sub-reservoir' was still good. In 2014, there still was no improvement in $\mathrm{WQI}_{C O D}$ even the scale of pollution distributed all reservoir (figure 4c). The management board should implement efficient solutions to solve this situation to give back the original water quality of lake

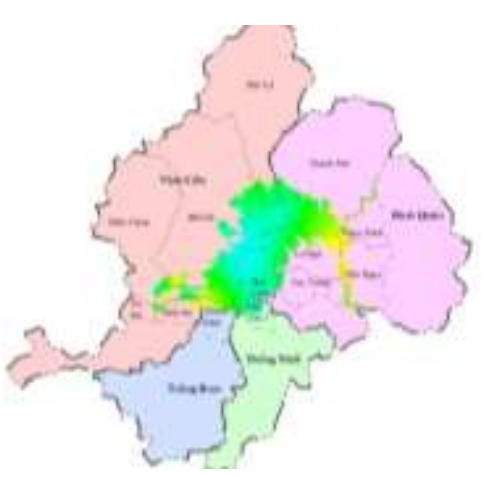

a) 2010

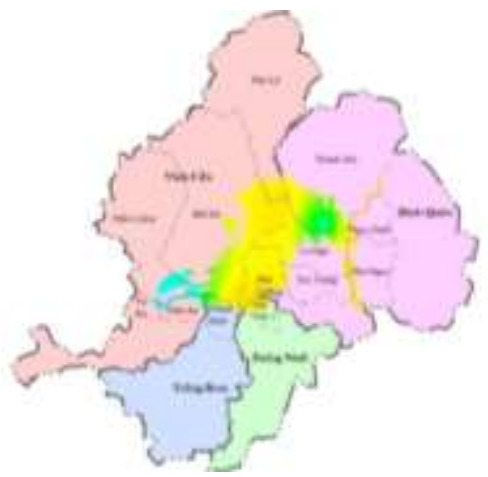

b) 2013

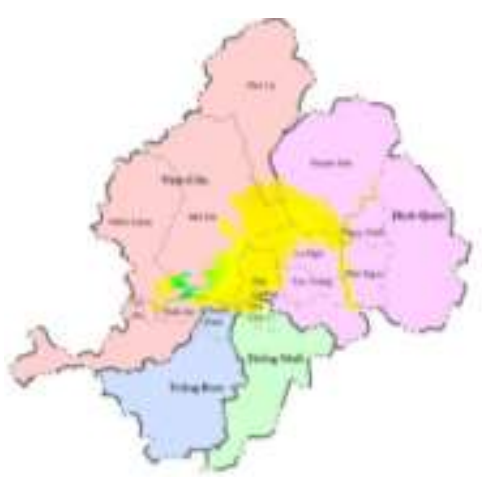

c) 2014

$$
\text { Note: } \quad(91,100) ; \quad(76,90) ; \quad(50,75) ; \quad \square \quad(25,50) ; \quad \square(1,25) \text {; }
$$

Figure 4: Tendency of $W Q I_{C O D}$

\section{4) $\mathbf{W Q I} \boldsymbol{I}_{\text {BOD5 }}$}

From the calculated $\mathrm{WQI}_{B O D 5}$ and interpolated results, the tendency of $\mathrm{WQI}_{B O D 5}$ of Tri An surface water changed for better but not much. In general, the parameter of
$\mathrm{WQI}_{B O D 5}$ was still good which was suitable for running water.

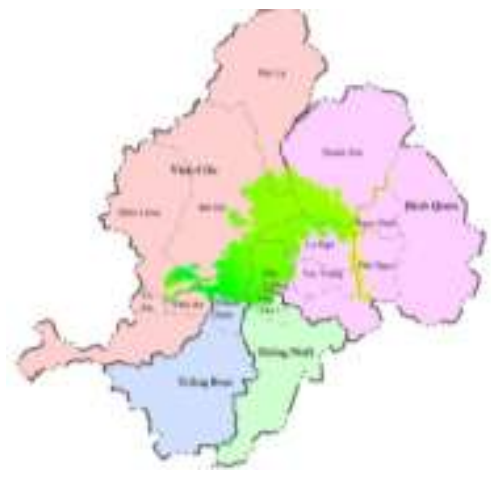

a) 2010

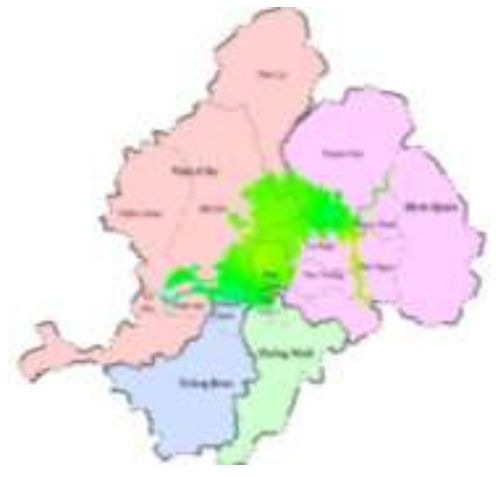

b) 2013

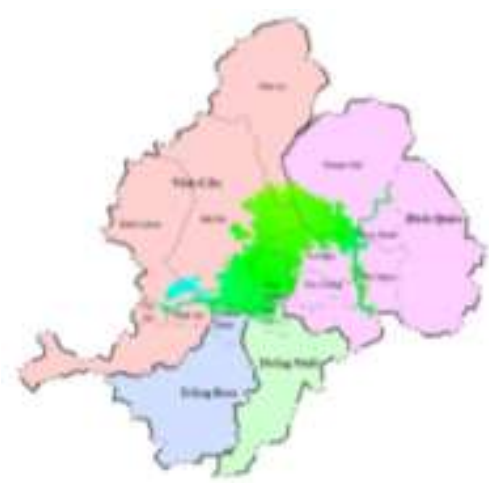

c) 2014

$$
\text { Note: } \quad(91,100) ; \quad \square \quad(76,90) ; \quad \quad(50,75) ; \quad \square \quad(25,50) ; \quad \square(1,25) \text {; }
$$

Figure 5: Tendency of $W Q I_{B O D 5}$

\section{5) $\mathrm{WQI}_{\mathrm{NH}_{4^{+}}}$}

From the figure 6 , we can see there was a significant decrease in parameter of $\mathrm{WQI}_{\mathrm{NH}_{4}+}$ in lake. To be detailed, the water quality was still very good in 2010 - get standard for running water. However, in 2014 the North of lake 
which run through some districts namely Ma Da, Phu Ly, Thanh Son, and La Nga had the bad quality. It fluctuated from 72 to 75 - only get standard for cultivation. The South of the lake, the water quality was better than the north and it could use for running water with suitable water use.

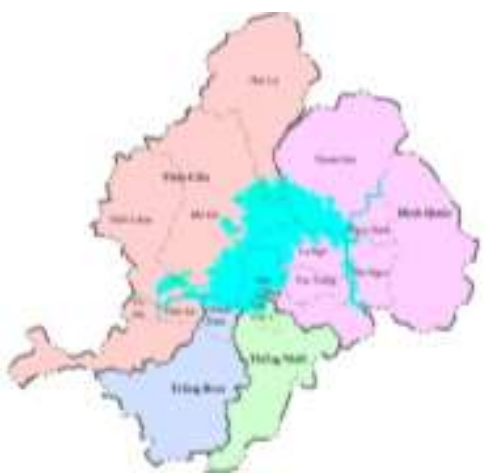

a) 2010

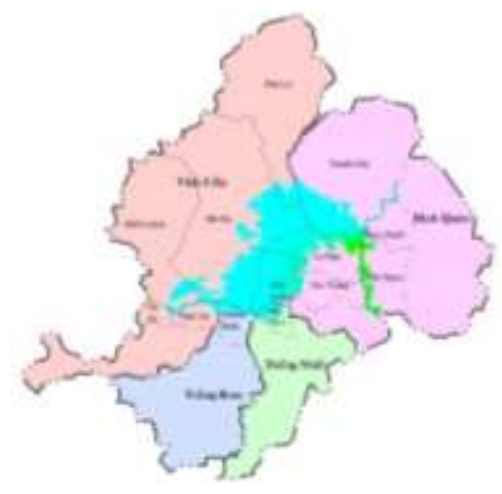

b) 2013

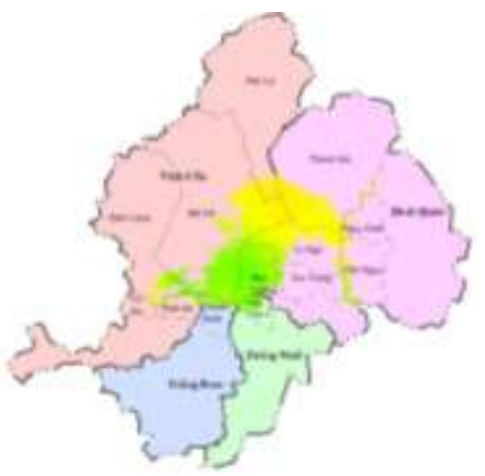

c) 2014
Note: $\quad(91,100)$;
$(76,90)$;
$(50,75)$;
$(25,50)$;
$(1,25)$

Figure 6: Tendency of $W Q I_{N H 4+}$

\section{6) WQI $I_{T S S}$}

The parameter of $\mathrm{WQI}_{T S S}$ in the North of Tri An reservoir which belong to two district namely $\mathrm{Ma} \mathrm{Da}$ and Phu Cuong fluctuated from 44 to 75 in 2010 (Fig. 7a). The water quality of this area was worse than remained areas of the lake and it only was suitable for river traffic and cultivation. However, there was an upward tendency in water quality in 2013 and 2014 (Fig. 7b, 7c). The quality of the lake wavered from 90 to 100 in some districts such as Ma Da, La Nga, Phu Cuong, Gia Tan, Thanh Binh, Vinh An, and Hieu Liem whereas there was no change in water quality in two districts Phu Ly and Thanh Son compared to 2010.

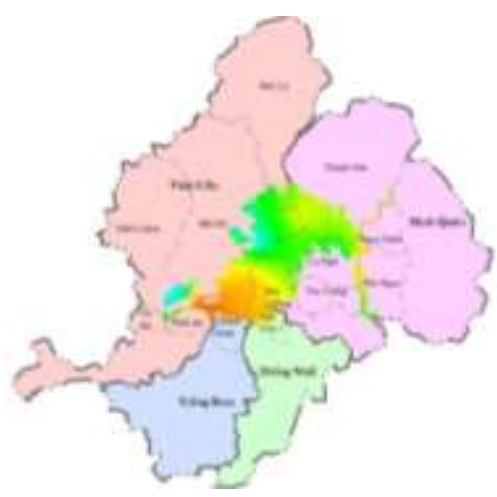

a) 2010

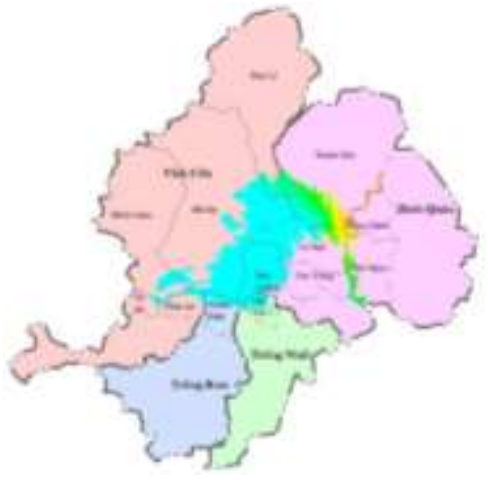

b) 2013

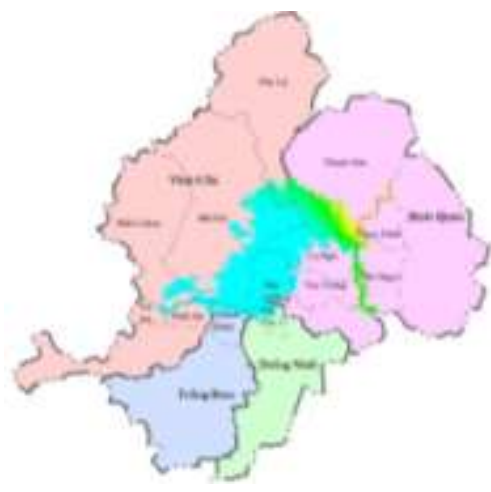

c) 2014

$$
\text { Note: } \quad(91,100) ; \quad(76,90) ; \quad \quad(50,75) ; \quad \square \quad(25,50) ; \quad 1,25) \text {; }
$$

Figure 7: Tendency of $W Q I_{T S S}$

\section{7) WQI Colifor}

In 2010 , the quality of reservoir was polluted significant because of organisms. In strict $\mathrm{Ma} \mathrm{Da}$, and Thanh Binh had $\mathrm{WQI}_{\text {Coli }}$ very low- at an alarming rate, the $\mathrm{WQI}_{\text {Coli }}$ wavered from 1 to 50. In 2013, there was an increase in the water quality in coliform and this situation still remained until to 2014. The parameter fluctuated from 89 to 100 ( 8 ). 


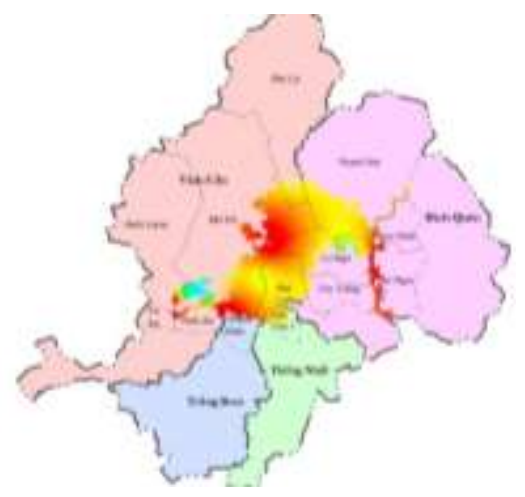

a) 2010

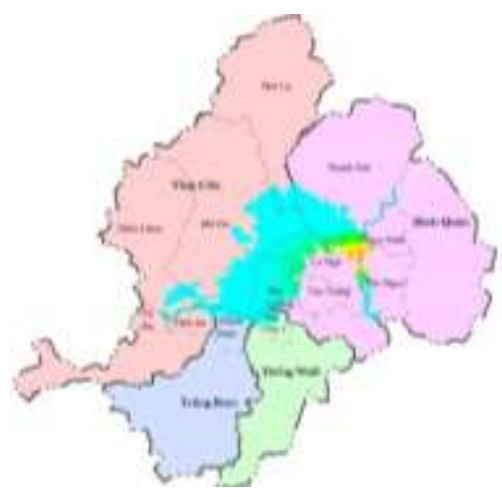

b) 2013

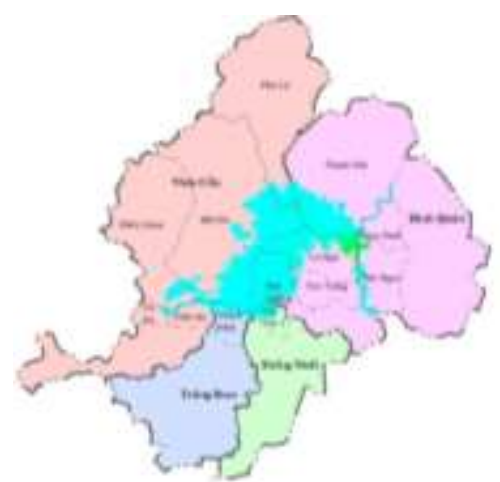

c) 2014

Note: $\quad(91,100) ; \quad(76,90) ; \quad(50,75) ; \quad \square(25,50) ; \quad \square(1,25)$;

Figure 8: Tendency of $W Q I_{\text {Coliform }}$

\section{8) WQI Iurbility $_{\text {th }}$}

The $\mathrm{WQI}_{B O D 5}$ in 2010 was in a situation at an alarming rate. Most of WQI ${ }_{\text {turbility }}$ in this year were under 26 and even in some positions WQI $\mathrm{I}_{\text {turbility }}$ were at red level. However, there was considerable improvement in $\mathrm{WQI}_{\text {turbility }}$ in 2013

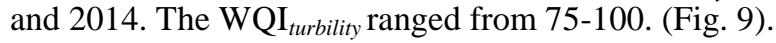

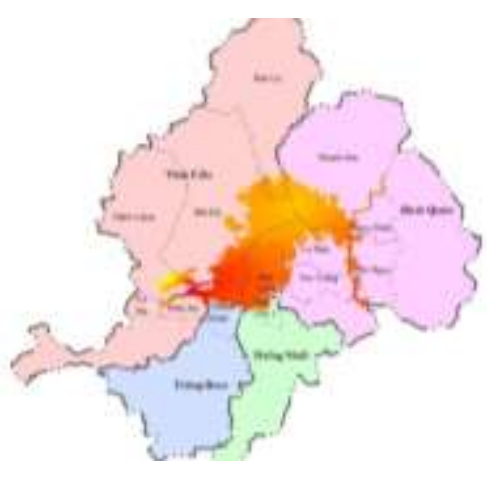

a) 2010

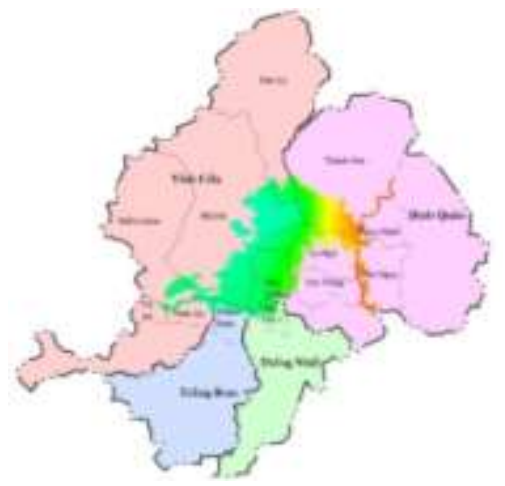

b) 2013

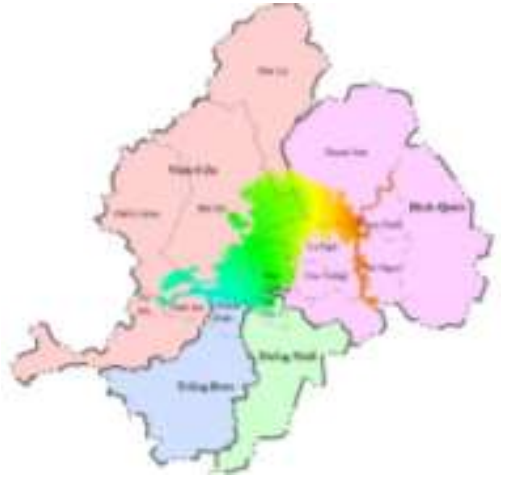

c) 2014

$$
\text { Note: } \quad(91,100) ; \quad \square(76,90) ; \quad \quad(50,75) ; \quad \square(25,50) ; \quad \square(1,25) \text {; }
$$

Figure 9: Tendency of $W Q I_{\text {turbility }}$

\section{9) WQIP-PO4}

According to calculated value of $\mathrm{WQI}_{P-P O 4}$ and interpolated result of $\mathrm{WQI}_{P-P O 4}$ (all of value of $\mathrm{WQI}_{p H}$ are equal 100) in three years 2010, 2013 and 2014. P-PO4

\section{0) WQI total}

The values of $\mathrm{WQI}_{\text {total }}$ were calculated based on parameters $\mathrm{pH}, \mathrm{DO}, \mathrm{BOD}_{5}, \mathrm{TSS}, \mathrm{NH}_{4}{ }^{+}, \mathrm{P}-\mathrm{PO} 4$, turbility and Coliform. Therefore, this parameter would a general view about the water quality of Tri An reservoir. The partial indicator in surface water in Tri An reservoir is still excellent. Therefore, the management board should control closely to remain this high level.

values for example coli form only present the microbial indictor in surface water, does not manifest the total quality of surface water. It can be seen from the Fig. 10, the surface water quality was extremely polluted especially in La Nga 
bridge, Thanh Binh district, Ma Dao districts. It was at red level - fluctuated form 16 to 20. In 2013 and 2014, the quality of water in Tri An lake improved significantlyfluctuated from 66 to 99 .

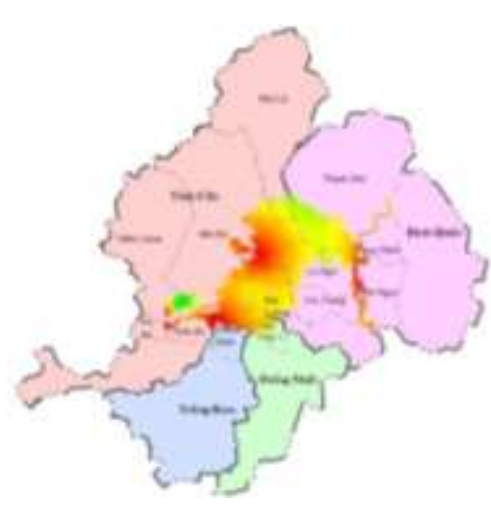

a) 2010

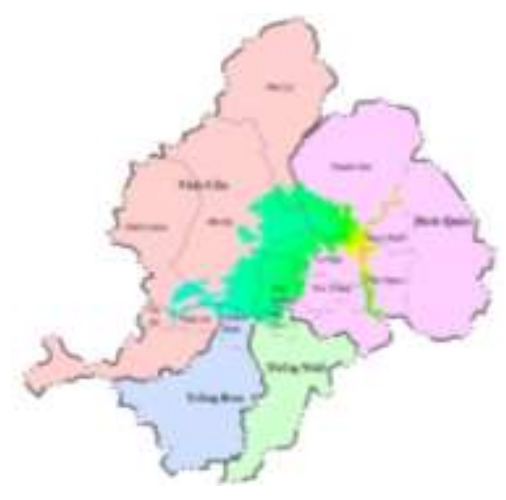

b) 2013

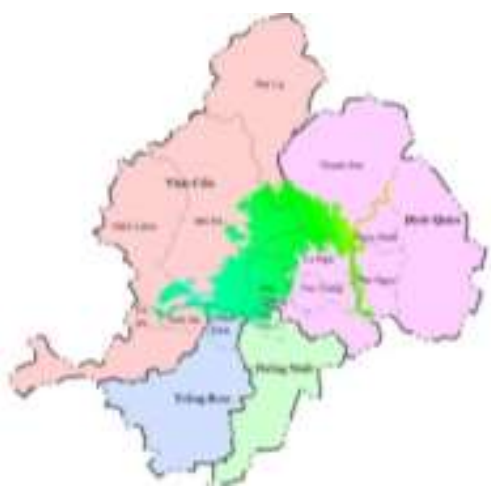

c) 2014

Note: $\quad(91,100) ; \quad \square(76,90) ; \quad \square(50,75) ; \quad \square(25,50) ; \quad \square(1,25)$;

Figure 10: Tendency of $W Q I_{\text {tota }}$

\section{Iv. Conclusion}

GIS tool and IDW function are applied in several projects related surface water management because of their powerful ability in analyzing and integrating metadata. However, there are occurrences of errors because the value of unmeasured positions would be interpolated by the value of measured positions which are closest to the unmeasured values. Moreover, a number of samples are not great (only 11 samples), ignore other factors such as speed of flow, the rainfall or discharged output etc lead to the errors in interpolation processing. Yet, these errors could be ignored because the interpolated values are still in the scale of Table 1 .

\section{References}

[1] DNFC, Annual technical reports on fisheries activities of Tri An reservoir from 1987-2005 (In Vietnamese), Department of Agriculture and Rural Development, Dong Nai, 2005.

[2] N.T. Tung, N.V. Trong \& L.N. Chau, "Survey on fish composition in Tri An reservoir (In Vietnamese)", RIA2, Ho Chi Minh, 2004.

[3] I.G. Cowx, "Principles and approaches to the management of lake and reservoir fisheries", in Management and ecology of lake and reservoir fisheries, I.G. Cowx, Fishing News Books. Blackwell Science, Eds. Oxford, 2002, pp. 336-393.

[4] D. Coates, "Inland capture fishery statistics of Southeast Asia: current status and information needs", FAO Regional Office for Asia \& Pacific, Bangkok, 2002.
[5] TTXVN, Môi trường nước hồ Trị An bị ô nhiễm, Trung tâm Quan trắc và Kỹ thuật Môi trường Đồng Nai, view 5/5/2015

[6] S. Yammani, "Groundwater quality suitable zones identification: application of GIS, Chittoor area, Andhra Pradesh, India", Environ. Geol, vol. 53, 2007, pp. 201210.

[7] K. Rangzan, A. Charchi A, Abshirini E and Dinger J Remote sensing and GIS approach for water-well site selection, Southwest Iran", Environ. Eng. Geosci, vol.14, 2008, pp. 315-326.

[8] I. S. Babiker, A. M, Mohamed and T. Hiyama," Assessing groundwater quality using GIS", Water Resour. Manage, vol.21, 2007, pp. 699-715.

[9] V. R. Rajkumar and M. K. Sneha, "Water quality analysis of Bhadravathi taluk using GIS - a case study", International Journal of Environmental Science, vol. 2, 2012, pp.2443-2453.

[10] N. Donia, "Water quality management of lake Temsah, Egypt using geographical information system (GIS)", International Journal of Environmental Science and Engineering, vol. 2, 2011, pp.1-8.

[11]S. K. Kumar, N. N. Karthikeyan and M. C. Sashikkumar, "Surface water quality monitoring for Thamirabarani River basin, Tamil Nadu using GIS", International Journal of Remote Sensing \& Geoscience (IJRSG), vol. 2, 2011, pp. 24-29.

[12] Bộ Tài nguyên và Môi trường - Quyết định về việc ban hành sổ tay tính toán chỉ số chất lượng nước' số: 879/QĐ-TCMT,

2011: http://thuvienphapluat.vn/archive/Quyet-dinh/. 